\title{
Comparison of phenol content and antioxidant capacity of nuts
}

\author{
Comparação entre o conteúdo de fenólicos e capacidade antioxidante de sementes
}

\author{
Lucile Tiemi $\mathrm{ABE}^{1}$, Franco Maria LAJOLO ${ }^{1}$, Maria Inés GENOVESE ${ }^{1 *}$
}

\begin{abstract}
Frequent nut intake is associated with protective effects against cardiovascular diseases. In addition to the generally high contents of unsaturated fatty acids, polyphenol compounds seem to be also implicated in health promoting effects of nuts due to their antioxidant properties. In this way, eleven different kinds of nuts, including pinhao seeds (Araucaria angustifolia) and Brazil nuts (Bertholletia excelsa), typical of Brazil, were analyzed for the content of phenol compounds, including the potent anti-mutagenic and anti-cancer ellagic acid, and antioxidant capacity of methanolic extracts. The antioxidant capacity varied a hundred times among the different nuts, from 1.2 to 120 mg of Trolox equivalents. $100 \mathrm{~g}^{-1}$ (FW). Total ellagic acid was determined after acid hydrolysis of ellagitannins and ellagic acid glycosides, and it was detected in only 3 of the 11 samples. The content of free and total ellagic acid in nuts varied from 0.37 to 41 and from 149 (chestnuts) to 823 (walnuts) mg.100 g $\mathrm{g}^{-1}$ (FW), respectively. Among nuts, samples with the highest contents of ellagic acid (walnuts and pecans) also presented the highest total phenol contents and DPPH radical scavenging capacities. Pinhao seeds and Brazil nuts did not present significant amounts of phenols nor antioxidant capacity.
\end{abstract}

Keywords: antioxidant capacity; ellagic acid; phenols; nuts; pinhao seeds; Brazil nuts.

\section{Resumo}

O consumo frequente de nozes está associado a efeitos protetores contra doenças cardiovasculares. Além do alto teor de ácidos graxos insaturados, os compostos polifenólicos também parecem implicados nos efeitos promotores da saúde devido a suas propriedades antioxidantes. Desta forma, onze tipos de nozes/sementes, incluindo pinhão (Araucaria angustifolia) e castanha-do-pará (Bertholletia excelsa), típicos do Brasil, foram analisados em relação ao seu conteúdo de fenólicos, incluindo ácido elágico, tido como potente antimutagênico e anticancerígeno, e capacidade antioxidante dos extratos metanólicos. A capacidade antioxidante variou cem vezes entre as diferentes amostras, de 1,2 a 120 mg equivalentes de Trolox.100 $\mathrm{g}^{-1}$ (b.u.). O ácido elágico total, determinado após hidrólise ácida dos elagitaninos e glicosídeos de ácido elágico, foi detectado em apenas 3 amostras. Os conteúdos de ácido elágico livre e total variaram de 0,37 a 41 e de 149 (castanha portuguesa) a 823 (nozes) $\mathrm{mg} .100 \mathrm{~g}^{-1}$ (b.u.), respectivamente. As amostras com os maiores teores de ácido elágico (nozes e pecans) também apresentaram os conteúdos de fenólicos totais e a capacidade de sequestro do radical DPPH mais elevados. O pinhão e a castanha-do-pará não apresentaram quantidades significativas de fenólicos nem elevada capacidade antioxidante.

Palavras-chave: capacidade antioxidante; ácido elágico; fenólicos; nozes; pinhão; castanha-do-pará.

\section{Introduction}

Several studies indicate that frequent nut intake (a serving per day, of $\sim 28$ to $100 \mathrm{~g} / \mathrm{d}$ ) confers protective effects against cardiovascular disease. In general, nuts have high lipid contents but with favorable profiles for promoting cardiovascular health, since they are low in saturated fatty acids and high in mono and polyunsaturated fatty acids. Studies connecting nut consumption and cardiovascular health disease have focused on fatty acid constituents; however there are other bioactive compounds that may confer additional protective effects. Kris-Etherton et al. (1999) demonstrated a significant decrease in LDL-cholesterol levels by replacing saturated fatty acids with unsaturated fatty acids in the diet. It was even observed that nut intake (walnut, hazelnut, macadamia, and almond) had higher effects than the intake of the same fatty acid profile, confirming the effects of additional compounds such as phytosterols and phytochemicals.

Epidemiological studies show that many polyphenol compounds present in fruits, vegetables, nuts, wine and tea are partly responsible for their beneficial health effects. Phenol compounds are secondary metabolites with considerable physiological and metabolic importance in plants. These compounds play an important role in growth and reproduction, providing protection against pathogens and predators (BRAVO, 1998). Among phenol phytochemicals, ellagic acid has been target of many studies and has shown important biological functions. One of the most studied properties of ellagic acid and ellagitannins is their antioxidant capacity in vitro (MEYER et al., 1998; GIL et al., 2000; MULLEN et al., 2002; BUSHMAN et al., 2004). Antioxidants are compounds that hinder oxidative processes and thereby delay or prevent oxidative stress. Oxidative stress is caused by excess of free radicals due to lifestyle and pathological situations and it has been related to cardiovascular disease, cancer and other chronic diseases that account for a major portion of deaths today (WILLCOX et al., 2004). Other important biological activities were also demonstrated for ellagic acid: potential to induce cell death and suppress proliferation in 
leukemia cells (MERTENS-TALCOTT et al., 2003); preventive effect of esophageal cancer in animals (WHITLEY et al., 2003); selective inhibition of the growth of human pathogenic bacteria (PUUPPONEN-PIMIÄ et al., 2001); and inhibition of in vitro plasma and LDL oxidation, showing its antiatherogenic potential (ANDERSON et al., 2001).

The main sources of ellagic acid are blackberries, raspberries, pomegranate and walnuts (DANIEL et al., 1989; CLIFFORD; SCALBERT, 2000). Pinto et al. (2008) reported the levels of ellagic acid in seven strawberry varieties cultivated in Brazil. There are no other reports about the ellagic acid content in foods consumed by the Brazilian population, which makes it necessary to find new potential sources of this compound.

According to this, the objective of this study was to evaluate the content of total phenols and ellagic acid, and the antioxidant capacity of eleven kinds of nuts, including those native from Brazil, namely pinhao seeds and Brazil nuts.

\section{Materials and methods}

\subsection{Samples}

Fresh nuts (two kilograms of each) were obtained from the Central Market of São Paulo, Brazil (CEAGESP). All samples (edible portions) were thoroughly homogenized by powdering in liquid nitrogen and stored at $-80^{\circ} \mathrm{C}$ under $\mathrm{N}_{2}$ until the time of analysis. Nut samples with high lipid contents were previously defatted with a Soxhlet extraction apparatus, using hexane as the solvent (excepting pinhao seeds and chestnut).

\subsection{Chemicals}

The HPLC standard ellagic acid, the 2,2-diphenyl1-picrylhydrazyl (DPPH'), and the Folin-Ciocalteu reagents were purchased from Sigma Co (St. Louis, MO). The hydroxy2,5,7,8-tetramethylchroman-2-carboxylic acid (Trolox) was from Aldrich (Milwaukee, WI). All chemicals and solvents used were analytical or HPLC grade when necessary.

\subsection{Moisture determination}

The moisture was measured in triplicate by drying at $70{ }^{\circ} \mathrm{C}$ under vacuum, according to the AOAC (1995). Results were expressed as a percentage.

\subsection{Lipid determination}

Lipid content was determined in triplicate according to the AOAC (1995), using hexane as the solvent. Analyses were made in triplicate and results expressed as a percentage (g.100 g $\mathrm{g}^{-1}$ in fresh weight).

\subsection{Sample extraction for total phenols and antioxidant capacity assays}

Samples were homogenized using a Brinkmann homogenizer (Polytron-Kinematica GmbH, Kriens-Luzern) with methanol/ water (70:30), in an ice bath, and filtered under reduced pressure through filter paper (Whatman No. 1).

\subsection{Total phenols}

The analysis was performed according to Singleton et al. (1999), with some modifications (GENOVESE et al., 2003). A $0.25 \mathrm{~mL}$ aliquot of the extract obtained above was mixed with 0.25 $\mathrm{mL}$ of the Folin-Ciocalteu reagent and $2 \mathrm{~mL}$ of distillated water. After 3 minutes at room temperature, $0.25 \mathrm{~mL}$ of a saturated sodium carbonate $\left(\mathrm{Na}_{2} \mathrm{CO}_{3}\right)$ solution was added and the mixture placed at $37^{\circ} \mathrm{C}$ in a water bath for 30 minutes. The absorbance was measured at $750 \mathrm{~nm}$ using a model Ultrospec $2000 \mathrm{UV} /$ visible spectrophotometer (Amersham Biosciences, Cambridge, U.K.). Gallic acid was used as the reference standard, and the results were expressed as $\mathrm{mg}$ of gallic acid equivalents. $100 \mathrm{~g}^{-1}$ sample in fresh weight (FW).

\subsection{Antioxidant capacity}

The antioxidant capacity was determined by the DPPH (2,2-diphenyl-1-picrylhydrazyl) radical-scavenging method according to the method of Brand-Williams et al. (1995), with some modifications (DUARTE-ALMEIDA et al., 2006). A $50 \mu \mathrm{L}$ aliquot of the extract previously diluted and $250 \mu \mathrm{L}$ of DPPH $(0.5 \mathrm{mM})$ were mixed and after 20 minutes the absorbance was measured at $517 \mathrm{~nm}$ using a Microplate Spectrophotometer (Benchmark Plus, BioRad, Hercules, CA). The control consisted of a methanolic solution of Trolox (6-hydroxy-2,5,7,8-tetramethylchroman-2-carboxylic acid) at different concentrations. The antioxidant capacity was expressed as $\mu$ moles Trolox equivalents. $g^{-1}$ sample in fresh weight (FW).

\subsection{Ellagic acid extraction}

Different solvents were tested to determine the best one for the extraction of ellagic acid derivatives from nuts, as follows: $80: 20 \mathrm{v} / \mathrm{v}$ acetone:water, 70:30 v/v methanol:water, $100 \%$ methanol, 80:20 v/v ethanol:water, and 70:30 v/v ethanol:water. The sample $(1 \mathrm{~g})$ was extracted three times $(100 \mathrm{~mL}$ the first time, $50 \mathrm{~mL}$ the next two times) in the solvent, in an ice bath, using a Brinkmann homogenizer (Polytron-Kinematica GmbH, Kriens-Luzern). The homogenate was filtered under reduced pressure through filter paper (Whatman $\mathrm{N}^{\circ} 1$ ), and the three fractions were combined. An aliquot of this extract was taken and hydrolyzed as follows.

\subsection{Total ellagic acid content}

Total ellagic acid was determined after acid hydrolysis according to the method of Pinto et al. (2008). An aliquot of $2 \mathrm{~mL}$ of the extract in $80 \%$ acetone, obtained as above, was dried under nitrogen and after this $2 \mathrm{~mL}$ of $2 \mathrm{~N}$ TFA were added and the hydrolysis was performed at $120^{\circ} \mathrm{C}$ for 90 minutes. The hydrolyzed samples were evaporated to dryness under nitrogen, redissolved in methanol and filtered through a $0.22 \mu \mathrm{m}$ PTFE (polytetrafluoroethylene) filter (Millipore Ltd., Bedford, MA) for HPLC analysis.

\subsection{HPLC quantification}

Identification and quantification of ellagic acid were achieved using analytical reversed-phase HPLC in a Hewlett- 
Packard 1100 system with autosampler and quaternary pump coupled to a diode array detector controlled by Chemstation software. The column used was $250 \times 4.6 \mathrm{~mm}$, i.d., $5 \mu$, Prodigy ODS3 reversed phase silica (Phenomenex Ltd., Torrance, CA) and elution solvents were: $\mathrm{A}$, water:tetrahydrofuran:trifluo roacetic acid (98:2:0.1) and B, acetonitrile. Solvent gradient was the same as that used by Arabbi et al. (2004). Eluates were monitored at 270 and $370 \mathrm{~nm}$ and samples were injected in duplicate. Calibration was performed by injecting the standards three times at five different concentrations $\left(R^{2} \geq 0.999\right)$. Peak identification was performed by comparison of retention time and diode array spectral characteristics with the standard. All analyses were done in triplicate and results were expressed as mg per $100 \mathrm{~g}$ of sample in fresh weight (FW).

\subsection{Statistical analysis}

All analyses were run in triplicate and results were expressed as mean \pm standard deviation (SD). Statistical analysis was done by using the Statistic software package version 5.0 (StatSoft, Inc., Tulsa, OK). Differences between means were first analyzed by ANOVA test and then Least Significant Difference (LSD) test $(p<0.05)$. Data were subjected to Pearson correlations.

\section{Results and discussion}

\subsection{Moisture and lipid contents}

The eleven different kinds of nut analyzed in this study presented moisture contents of the edible portions ranging from $<1$ to $52 \%$. Most of the nuts presented low water contents $(<10 \%)$ excepting chestnuts and pinhao seeds $(\sim 50 \%)$. On the other hand, the lowest lipid contents were those of chestnuts and pinhao seeds, and the highest ones those of walnuts, pecans and Brazil nuts (71-72\%) (Table 1).

\subsection{Total phenol content}

The identification of new dietary sources of phenol compounds is of great interest for public health. The nuts analyzed in this study are consumed all around the world and also locally, such as pinhao seeds, though they also represent good perspectives for agro-industrial purposes. The content of total phenols of nuts varied greatly, from 50 to $2499 \mathrm{mg} .100 \mathrm{~g} \mathrm{~g}^{-1}$
(FW) (Table 2). The phenol content in descending order was walnuts $>$ pecans $>$ peanuts $>$ pistachios $>$ cashew nuts $>$ almonds $>$ hazelnuts $>$ Brazil nuts $>$ chestnuts $>$ macadamias $>$ pinhao seeds.

The levels of phenol compounds in nuts are influenced by environmental factors, soil composition, and maturation level, similar to what is observed for fruits and vegetables (WAKELING et al., 2001). Similar to our results, Wu et al. (2004) reported total phenol contents ranging from 68 to $2016 \mathrm{mg} \cdot 100 \mathrm{~g}^{-1}$ for 10 nut varieties. Kornsteiner et al. (2006) also reported the highest values for walnuts (from 1020 to $2052 \mathrm{mg} \cdot 100 \mathrm{~g}^{-1} \mathrm{FW}$ ), followed by pecans (from 1022 to $1444 \mathrm{mg} .100 \mathrm{~g} \mathrm{~g}^{-1} \mathrm{FW}$ ) and pistachios (from 492 to $1442 \mathrm{mg} .100 \mathrm{~g}^{-1} \mathrm{FW}$ ).

In spite of the low content of phenols reported here for raw pinhao, it is important to take into account that normally the seeds are cooked in water, in the presence of the seed coat, before consumption. Under these conditions, Cordenunsi et al. (2004) observed that there is a migration of phenols from the seed coat, including quercetin, into the seed.

\subsection{Antioxidant capacity}

The methanolic extracts derived from nuts were evaluated for antioxidant capacity by the DPPH radical scavenging method, which is based on the measurement of the reducing ability of antioxidants toward the radical DPPH. In this reaction, the methanolic solution of DPPH changes from purple to light yellow and the degree of discoloration, evaluated spectrometrically at $517 \mathrm{~nm}$, indicates the free radical scavenging potential of the antioxidant compound (PRIOR et al., 2005). The antioxidant capacity varied a hundred times among the different nuts, from 1.2 to $120 \mathrm{mg} .100 \mathrm{~g} \mathrm{~g}^{-1}$ (FW) (Table 2). Most of the samples presented values below $10 \mu \mathrm{mol}$ of Trolox equivalents. $\mathrm{g}^{-1}$, except for walnuts $\left(120 \mu \mathrm{mol}\right.$ of Trolox equivalents. $\left.\mathrm{g}^{-1}\right)$ and pecans $\left(58 \mu \mathrm{mol}\right.$ of Trolox equivalents. $\left.\mathrm{g}^{-1}\right)$, with extremely high $\mathrm{DPPH} \cdot$ scavenging activities. A high correlation $(r=0.93)$ was observed between total phenol content and antioxidant capacity of nuts.

A good correlation between total phenols and DPPH scavenging activity was previously found for Brazilian native fruits $(\mathrm{r}=0.997)$ (GENOVESE et al., 2008) and dry beans (Phaseolus vulgaris) cotyledons (RANILLA et al., 2007).

Table 1. Scientific and common names and water and lipid contents (\%) of nuts evaluated in this study.

\begin{tabular}{|c|c|c|c|c|}
\hline Family & Scientific name & Common name & Moisture (\%) & Lipids (\%) \\
\hline \multirow[t]{2}{*}{ Anacardiaceae } & Anacardium occidentale Linnaeus & Cashew nut (raw) & $4.5 \pm 0.2^{c}$ & $42 \pm 1^{\mathrm{f}}$ \\
\hline & Pistacia vera Linnaeus & Pistachio (toasted) & $<1^{\mathrm{e}}$ & $45 \pm 1^{\mathrm{e}}$ \\
\hline Araucariaceae & Araucaria angustifolia (Bertol.) Kuntze & Pinhao seeds (raw) & $52 \pm 2^{\mathrm{a}}$ & $0.81 \pm 0.03^{\mathrm{h}}$ \\
\hline Leguminosae & Arachis hypogaea Linnaeus & Peanuts (raw) & $6.5 \pm 0.1^{\mathrm{b}}$ & $57 \pm 1^{\mathrm{d}}$ \\
\hline Fagaceae & Castanea sativa Mill & Chestnut (raw) & $50 \pm 1^{\mathrm{a}}$ & $5.8 \pm 0.3^{g}$ \\
\hline Lecythidaceae & Bertholletia excelsa Humb. \& Bonpl. & Brazil nut (raw) & $<1^{\mathrm{e}}$ & $71 \pm 3^{\mathrm{a}}$ \\
\hline Proteaceae & Macadamia integrifolia Maiden \& Betche & Macadamia (dehydrated) & $<1^{\mathrm{e}}$ & $60 \pm 1^{c}$ \\
\hline Rosaceae & Prunus dulcis (Mill.) D.A. Webb & Almond (toasted) & $<1^{\mathrm{e}}$ & $55 \pm 2^{\mathrm{d}}$ \\
\hline
\end{tabular}


The high phenol content and antioxidant capacity of methanolic extracts of walnuts and pecans indicate that the beneficial health effects would not be restricted to the lipidic fraction. Most importantly, in contrast to cashew nuts, pinhao seeds, peanuts and chestnuts, which are normally consumed toasted or cooked, walnuts and pecans are consumed in the raw form, which preserves phenol compounds from eventual thermal degradation and guarantees their antioxidant potential. In fact, these nuts are known for the high content of the antiproliferative, antimutagenic and antioxidant ellagic acid, whose content was determined and presented below.

\subsection{Solvent test}

Ellagic acid can exist as free form, glycoside or linked as ellagitannins esterified with glucose (BATESMITH, 1972). In foods, ellagic acid is mainly found as polymeric ellagitannins and, for their detection and quantification, the sample is normally subjected to an acid hydrolysis. When exposed to acid, ester bonds are hydrolyzed forming the hexahydroxydiphenic acid, which spontaneously rearranges into the water-insoluble ellagic acid. However, although all the common analytical techniques for measuring ellagic acid have good accuracy and reproducibility, the results differ, depending on the method of extraction used (TOMÁS-BARBERÁN; CLIFFORD 2000; PINTO et al., 2008). According to this, different solvents were previously tested to determine the best one for extracting ellagitannins from defatted walnuts. The solvents were selected from those mentioned in the literature (YURITAS et al., 2000; STAMPAR et al., 2006; FUKUDA et al., 2003; ALASALVAR et al., 2006; WU et al., 2004), and the results are presented in Table 3. It can be noted that ellagitannins extraction was significantly higher when $80 \%$ aqueous acetone was used. There were no significant differences between $70 \%$ aqueous methanol, pure methanol and $70 \%$ aqueous ethanol, but the extraction with $80 \%$ aqueous ethanol was less efficient. It was concluded that $80 \%$ acetone was also the better solvent for extracting ellagitannins in nuts, similar to the results reported by Pinto et al. (2008) for strawberries.

Table 2. Total phenol content (mg.100 g $\left.\mathrm{g}^{-1} \mathrm{FW}\right)$ and antioxidant capacity ( $\mu \mathrm{mol}$ Trolox eq/g FW) of nuts.

\begin{tabular}{lcc}
\hline \multicolumn{1}{c}{ Nuts } & Total phenols & Antioxidant capacity \\
\hline Cashew nut (raw) & $381 \pm 6^{\mathrm{e}}$ & $3.0 \pm 0.1^{\mathrm{e}}$ \\
Pistachio (toasted) & $576 \pm 7^{\mathrm{d}}$ & $3.9 \pm 0.1^{\mathrm{d}}$ \\
Pinhao seeds (raw) & $50 \pm 3^{\mathrm{i}}$ & $3.1 \pm 0.3^{\mathrm{e}}$ \\
Hazelnut (toasted) & $111 \pm 2^{\mathrm{f}}$ & $4.2 \pm 0.4^{\mathrm{d}}$ \\
Peanuts (raw) & $597 \pm 6^{\mathrm{c}}$ & $5.9 \pm 0.3^{\mathrm{c}}$ \\
Chestnut (raw) & $92 \pm 2^{\mathrm{g}}$ & $6.2 \pm 0.5^{\mathrm{c}}$ \\
Walnut (raw) & $2499 \pm 94^{\mathrm{a}}$ & $120 \pm 10^{\mathrm{a}}$ \\
Pecan (raw) & $703 \pm 44^{\mathrm{b}}$ & $58 \pm 2^{\mathrm{b}}$ \\
Brazil nut (raw) & $106 \pm 7^{\mathrm{f}}$ & $2.6 \pm 0.2^{\mathrm{f}}$ \\
Macadamia (dehydrated) & $87 \pm 2^{\mathrm{h}}$ & $4.5 \pm 0.3^{\mathrm{d}}$ \\
Almond (toasted) & $114 \pm 3^{\mathrm{f}}$ & $1.2 \pm 0.2^{\mathrm{g}}$ \\
\hline
\end{tabular}

Results are expressed as means \pm SD for triplicates. Means in the same column with common letters are not significantly different $(\mathrm{p}<0.05)$.

\subsection{Total ellagic acid content}

A total of three out of the eleven nuts evaluated here presented ellagic acid in their composition, which was detected both in the free form (before acid hydrolysis) and released from glycosides and/or ellagitannins (after acid hydrolysis) (Table 4). The content of free ellagic acid varied from 0.37 to $41 \mathrm{mg} .100 \mathrm{~g} \mathrm{~g}^{-1}$ FW, corresponding to 0.25 to $5 \%$ of the total, showing that ellagic acid is mainly present as derivatives. Interestingly, the highest contents of total ellagic acid were found in walnuts and pecans, which belong to the same family (Juglandaceae).

The content of free and total ellagic acid in chestnut was 0.37 and $149 \mathrm{mg} .100 \mathrm{~g}^{-1}(\mathrm{FW})$, respectively. Chestnut woods and leaves are already known to have a high content of ellagic acid. Bianco et al. (1998) previously reported ellagic acid contents varying from 1.9 to $8.9 \mathrm{~g} .100 \mathrm{~g}^{-1}$ in chestnut wood.

For these three samples, a high correlation was observed between total phenols and ellagic acid content $(r=1.00)$, and antioxidant capacity and ellagic acid content $(r=0.97)$.

Walnuts and pecans evaluated in the present study presented higher ellagic acid contents than those reported in the literature, from 133 to $542 \mathrm{mg} .100 \mathrm{~g}^{-1}$ for walnuts (LI et al., 2006; CERDÁ et al., 2005) and from 250 to $473 \mathrm{mg} .100 \mathrm{~g}^{-1}$ of defatted sample for pecans (VILLARREAL-LOZOYA et al., 2007). Considering a lipid content of $70 \%$, this would correspond to values from 75 to $142 \mathrm{mg} .100 \mathrm{~g}^{-1}$ fresh weight. Similarly, Li et al. (2006) reported ellagic acid contents from 29 to $131 \mathrm{mg} .100 \mathrm{~g}^{-1}$

Table 3. Total ellagic acid content (mg.100 g $\left.{ }^{-1} \mathrm{FW}\right)$ of walnuts obtained using different extraction solvents.

\begin{tabular}{lc}
\hline \multicolumn{1}{c}{ Solvent } & Total ellagic acid \\
\hline acetone:water $80: 20 \mathrm{v} / \mathrm{v}$ & $872 \pm 40^{\mathrm{a}}$ \\
methanol:water $70: 30 \mathrm{v} / \mathrm{v}$ & $767 \pm 49^{\mathrm{b}}$ \\
100\% methanol & $739 \pm 51^{\mathrm{b}}$ \\
ethanol:water $80: 20 \mathrm{v} / \mathrm{v}$ & $627 \pm 23^{\mathrm{c}}$ \\
ethanol:water $70: 30 \mathrm{v} / \mathrm{v}$ & $747 \pm 36^{\mathrm{b}}$ \\
\hline
\end{tabular}

Results are expressed as means \pm SD for triplicates. Means in the same column with common letters are not significantly different $(\mathrm{p}<0.05)$.

Table 4. Free and total ellagic acid (EA) contents (mg.100 g ${ }^{-1}$ sample FW) of nuts.

\begin{tabular}{lccc}
\hline \multicolumn{1}{c}{ Family name } & Nuts & Free AE & Total AE \\
\hline Anacardiaceae & Cashew nut & n.d. & n.d. \\
& Pistachio & n.d. & n.d. \\
Araucariaceae & Pinhao seeds & n.d. & n.d. \\
Betulaceae & Hazelnut & n.d. & n.d. \\
Leguminosae & Peanuts & n.d. & n.d. \\
Fagaceae & Chestnut & $0.37 \pm 0,01^{\mathrm{c}}$ & $149 \pm 3^{\mathrm{c}}$ \\
Juglandaceae & Walnut & $41 \pm 1^{\mathrm{a}}$ & $823 \pm 59^{\mathrm{a}}$ \\
& Pecan & $15 \pm 1^{\mathrm{b}}$ & $301 \pm 7^{\mathrm{b}}$ \\
Lecythidaceae & Brazilian nut & n.d. & n.d. \\
Proteaceae & Macadamia & n.d. & n.d. \\
Rosaceae & Almond & n.d. & n.d. \\
\hline
\end{tabular}

Results are expressed as means \pm SD for triplicates. Means in the same column with different letters are significantly different $(\mathrm{p}<0.05)$. n.d. not detected. 
(FW) for pecans. If these differences are due to genetic and/or environmental conditions remains to be determined.

The recommendations to increase nut consumption for health benefits, including reduced cardiovascular disease risk, are supported by epidemiological and clinical studies showing an inverse association between the frequency of nut consumption and weight increase (MATTES et al., 2008). In addition to a favorable fatty acid profile, nuts contain protein, fiber, potassium, calcium, magnesium, tocopherols, phytosterols, and other bioactive compounds that explain their multiple cardiovascular benefits. In this way, it is not possible to attribute the benefits to a single class of compounds and/or estimate which would be the recommendable intake.

\section{Conclusion}

A large variation in phenols and antioxidant capacity was found in the nuts evaluated in the present study. The highest values of antioxidant capacity were associated with high amounts of phenols and/or ellagic acid. The main sources of ellagic acid among nuts evaluated in this study are those belonging to the Juglandaceae family. Although walnuts and pecans represent excellent sources of ellagic acid, these products are not commonly consumed by the Brazilian population, which warrants further studies for native foods rich in this potential beneficial compound.

\section{Acknowledgements}

We would like to acknowledge the Fundação de Amparo à Pesquisa do Estado de São Paulo (FAPESP) and the Coordenação de Aperfeiçoamento de Pessoal de Nível Superior (CAPES) for their financial support and a scholarship.

\section{References}

ALASALVAR, C. et al. Antioxidant and antiradical activities in extracts of hazelnut kernel (Corylus avellana L.) and hazelnut green leafy cover. Journal of Agricultural and Food Chemistry, v. 54, n. 13, p. 4826-4832, 2006.

ANDERSON, K. J. et al. Walnut polyphenolics inhibit in vitro human plasma and LDL oxidation. Journal of Nutrition, v. 131, p. 2837-2842, 2001.

ASSOCIATION OF OFFICIAL ANALYTICAL CHEMISTS - AOAC. Official methods of analysis. $16 \mathrm{ed}$. Washington, 1995.

ARABBI, P. R.; GENOVESE, M. I.; LAJOLO, F. M. Flavonoids in vegetable foods commonly consumed in Brazil and estimated ingestion by the Brazilian population. Journal of Agricultural and Food Chemistry, v. 52, n. 5, p. 1124-1131, 2004.

BATESMITH, E. C. Detection and determination of ellagitannins. Phytochemistry, v. 11, p. 1153-1156, 1972.

BIANCO, M. A.; HANDAJI, A.; SAVOLAINEN, H. Quantitative analysis of ellagic acid in hardwood samples. Science of the Total Environment, v. 222, p. 123-126, 1998.BRAND-WILLIAMS, W.; CUVELIER, M. E.; BERSET, C. Use of a free radical method to evaluate antioxidant activity. Food Science and Technology, v. 28, n. 1, p. 25-30, 1995.

BRAVO, L. Polyphenols: chemistry, dietary sources, metabolism, and nutritional significance. Nutrition Reviews, v. 56, n. 11, p. 317-333, 1998.
BUSHMAN, B. S. et al. Chemical composition of Caneberry (Rubus spp.) seeds and oil and their antioxidant potential. Journal of Agricultural and Food Chemistry, v. 52, n. 26, p. 7982-7987, 2004.

CERDÁ, B.; TOMÁS-BARBERÁN, F. A.; ESPÍN, J. C. Metabolism of antioxidant and chemopreventive ellagitannins from strawberries, raspberries, walnuts, and oak-aged wine in humans: Identification of biomarkers and individual variability. Journal of Agricultural and Food Chemistry, v. 53, n. 2, p. 227-235, 2005.

CLIFFORD, M. N.; SCALBERT, A. Ellagitannins: nature, occurrence and dietary burden. Journal of the Science of Food and Agriculture, v. 80, n. 7, p. 1118-1125, 2000.

CORDENUNSI, B. R. et al. Chemical Composition and Glycemic Index of Brazilian Pine (Araucaria angustifolia) Seeds. Journal of Agricultural and Food Chemistry, v. 52, n. 11, p. 3412-3416, 2004.

DANIEL, E. M. et al. Extraction, stability and quantitation of ellagic acid in various fruits and nuts. Journal of Food Composition and Analysis, v. 2, p. 338-349, 1989.

DUARTE-ALMEIDA, J. M. et al. Avaliação da atividade antioxidante utilizando sistema $\beta$-caroteno/ácido linoleico e método de sequestro de radicais DPPH. Ciência e Tecnologia de Alimentos, v. 26, n. 2, p. 446-452, 2006.

FUKUDA, T.; ITO, H.; YOSHIDA, T. Antioxidative polyphenols from walnuts (Juglans regia L.). Phytochemistry, v. 63, n. 7, p. 795-801, 2003.

GENOVESE, M. I. et al. Bioactive compounds and antioxidant capacity of exotic fruits and commercial frozen pulps from Brazil. Food Science and Technology Internacional, v. 14, n. 3, p. 207-214, 2008.

GENOVESE, M. I. et al. Determinação do conteúdo de fenólicos totais em frutas. Revista Brasileira de Ciências Farmacêuticas, v. 39, n. 3, p. 167-169, 2003.

GIL, M. I. et al. Antioxidant activity of pomegranate juice and its relationship with phenolic composition and processing. Journal of Agricultural and Food Chemistry, v. 48, n. 10, p. 4581-4589, 2000.

KORNSTEINER, M.; WAGNER, K.; ELMADFA, I. Tocopherols and total phenolics in 10 different nut types. Food Chemistry, v. 98, n. 2, p. 381-387, 2006.

KRIS-ETHERTON, P. M. et al. Nuts and their bioactive constituents: effects on serum lipids and other factors that affect disease risk. American Journal of Clinical Nutrition, v. 70, n. 3, p. 504S-511S, 1999.

LI, L. et al. Polyphenolic profiles and antioxidant activities of heartnut (Juglans ailanthifolia Var. cordiformis) and Persian Walnut (Juglans regia L.). Journal of Agricultural and Food Chemistry, v. 54, n. 21, p. 8033-8040, 2006.

MATTES, R. D.; KRIS-ETHERTON, P. M.; FOSTER, G. D. Impact of peanuts and tree nuts on body weight and healthy weight loss in adults. Journal of Nutrition, v. 138, n. 9, p. 1741S-1745S, 2008.

MERTENS-TALCOTT, S. U.; TALCOTT, S. T.; PERCIVAL, S. Low concentration of quercetin and ellagic acid synergistically influence proliferation, cytotoxicity and apoptosis in MOLT-4 Human leukemia cells. Journal of Nutrition, v. 133, p. 2669-2674, 2003.

MEYER, A. S.; HEINONEN, M.; FRANKEL, E. N. Antioxidant interactions of catechin, cyaniding, caffeic acid, quercetin, and ellagic acid on human LDL oxidation. Food Chemistry, v. 61, p. 71-75, 1998.

MULLEN, W. et al. Ellagitannins, flavonoids and other phenolics in red raspberries and their contribution to antioxidant capacity 
and vasorelation properties. Journal of Agricultural and Food Chemistry, v. 50, n. 18, p. 5191-5196, 2002.

PINTO, M. S.; LAJOLO, F. M.; GENOVESE, M. I. Bioactive compounds and quantification of total ellagic acid in strawberries (Fragaria $x$ ananassa Duch.). Food Chemistry, v. 107, n. 4, p. 1629-1635, 2008.

PRIOR, R. L.; WU, X.; SCHAICH, K. Standardized methods for the determination of antioxidant capacity and phenolics in foods and dietary supplements. Journal of Agricultural and Food Chemistry, v. 53, n. 10, p. 4290-4302, 2005.

PUUPPONEN-PIMIÄ, R. et al. Berry phenolics selectively inhibit the growth of intestinal pathogens. Journal of Applied Microbiology, v. 98, n. 4, p. 991-1000, 2001.

RANILLA, L. G.; GENOVESE, M. I.; LAJOLO, F. M. Polyphenols and antioxidant capacity of seed coat and cotyledon from Brazilian and peruvian bean cultivars (Phaseolus vulgaris L.). Journal of Agricultural and Food Chemistry, v. 55, n. 1, p. 90-98, 2007.

SINGLETON, V. L.; ORTHOFER, R.; LAMUELA-RAVENTÓS, R. M. Analysis of total phenols and other oxidation substrates and antioxidants by means of Folin-Ciocalteu reagent. Methods in Enzymology, v. 299, p. 152-178, 1999.

STAMPAR, F. et al. Traditional walnut liqueur: cocqtail of phenolics. Food Chemistry, v. 95, n. 4, p. 627-631, 2006.
TOMÁS-BARBERÁN, F. A.; CLIFFORD, M. N. Dietaryhydroxybenzoic acid derivatives: nature, occurrence and dietary burden. Journal of the Science of Food and Agriculture, v. 80, n. 7, p. 1024-1032, 2000.

VILLARREAL-LOZOYA, J. E.; LOMBARDINI, L.; CISNEROSZEVALLOS, L. Phytochemical constituents and antioxidant capacity of different pecan (Carya illinoiensis (Wangenh.) K. Koch) cultivars. Food Chemistry, v. 102, n. 4, p. 1241-1249, 2007.

WAKELING, L. T. et al. Composition of pecan cultivars Wichita and Western Schley (Carya illinoinensis (Wangenh.) K. Koch) grown in Australia. Journal of Agricultural and Food Chemistry, v. 49, n. 3, p. 1277-1281, 2001.

WHITLEY, A. C. et al. Intestinal epithelial cell accumulation of the cancer preventive polyphenol ellagic acid: extensive binding to protein and DNA. Biochemical Pharmacology, v. 66, n. 6, p. 907-915, 2003.

WILLCOX, J. K.; ASH, S. L.; CATIGNANI, G. L. Antioxidants and prevention of chronic disease. Critical Reviews in Food Science and Nutrition, v. 44, n. 4, p. 275-295, 2004.

WU, X. et al. Lipophilic and hydrophilic antioxidant capacities of common foods in the United States. Journal of Agricultural and Food Chemistry, v. 52, n. 12, p. 4026-4037, 2004.

YURITAS, H. C.; SCHAFER, H. W.; WARTHESEN, J. J. Antioxidant activity of nontocopherol Hazelnut (Corylus spp.) phenolics. Journal of Food Science, v. 65, n. 2, p. 276-280, 2000. 